\title{
1-Methylthio-3-lithioisoquinoline. The first simple isoquinoline derivative lithiated at the 3 -position
}

\author{
Joseph M. Muchowski \\ Chemistry, Roche Palo Alto, 3431 Hillview Avenue, Palo Alto, CA 94304, USA \\ E-mail: joseph.muchowski@roche.com
}

Dedicated to Eusebio Juaristi on the occasion of his $55^{\text {th }}$ birthday and in recognition of his many contributions to organic chemistry in México

(received 22 Jun 05; accepted 04 Oct 05; published on the web 07 Oct 05)

\begin{abstract}
1-Methylthio-3-lithioisoquinoline $\mathbf{5 a}$ is readily generated from 1-methylthio-3bromoisoquinoline $\mathbf{5 b}$ and $n$-butyllithium in THF solution at $-78{ }^{\circ} \mathrm{C}$. This lithium derivative was reacted with sundry electrophilic reagents to give various 1-methylthio-3-substitued isoquinolines 12. Two of the latter compounds ( $12 \mathbf{b}, \mathrm{R}=\mathrm{Me})$ and $\mathbf{1 2 f}\left(\mathrm{R}=\mathrm{CO}_{2} \mathrm{Me}\right)$ were desulfurized to the corresponding 3-substituted isoquinolines 16a and 16b. Lithio species 5a is thus formally equivalent to the hypothetical 3-lithioisoquinoline 3a.
\end{abstract}

Keywords: 1-Methylthio-3-lithioisoquinoline, 1-methylthio-3-substituted isoquinolines

\section{Introduction}

1-Lithioisoquinoline 1a and 4-lithioisoquinoline 2a (Scheme 1) were first generated by Gilman and Soddy ${ }^{1}$ from the corresponding bromo compounds $\mathbf{1 b}$ and $\mathbf{2 b}$ (Scheme1) by bromine-lithium inter-change with $n$-butyllithium, and these reagents have occasionally been used to prepare various 1-substituted isoquinoline ${ }^{2,3}$ and 4-substituted ${ }^{4-6}$ isoquinoline derivatives. Neither 3lithioisoquino-line 3a, nor any simple analog thereof has ever been reported, although the author is aware of at least one unsuccessful attempt ${ }^{7}$ to generate $3 \mathbf{a}$ from the bromo compound $\mathbf{3 b}$. It is well known, however, that 1,2,3-triazolo[5,1-a]isoquinoline $\mathbf{4 b}$ is readily converted into the 5lithio species $4 \mathbf{a}$ with lithium diisopropylamide, ${ }^{8-10}$ and the products derived therefrom can be transformed by diverse means into various 1,3 -disubstituted isoquinolines. ${ }^{8-10}$ 
<smiles>[R]c1nccc2ccccc12</smiles>

$1 \mathrm{a} \mathrm{R}=\mathrm{Li}$

1b $\mathrm{R}=\mathrm{Br}$<smiles>[R]c1cncc2ccccc12</smiles>

2a $\mathrm{R}=\mathrm{Li}$

2b $\mathrm{R}=\mathrm{Br}$<smiles>[R]c1cc2ccccc2cn1</smiles>

3a R $=\mathrm{Li}$

3b $\mathrm{R}=\mathrm{Br}$<smiles>[R]c1cc2ccccc2c2cnnn12</smiles>

$4 \mathrm{a} \mathrm{R}=\mathrm{Li}$

4b $\mathrm{R}=\mathrm{H}$<smiles>[R]c1cc2ccccc2c(SC)n1</smiles>

$5 \mathrm{a} \mathrm{R}=\mathrm{Li}$

\section{Scheme 1}

Herein are described preliminary results for a convenient route to 1-methylthio-3lithioisoquinoline 5a, the first simple 3-lithioisoquinoline derivative, and the reaction thereof with several electrophilic reagents.

\section{Results and Discussion}

The first phase of this study was focused on the possibility of generating 3-lithioisoquinoline 3a itself from 3-bromoisoquinoline 3b. To this end, 1,3-dibromoisoquinoline 6 (Scheme 2), readily available from homophthalimide ${ }^{11}$, was reacted with an equimolar amount of $n$-butyllithium in THF solution $\left(<-70{ }^{\circ} \mathrm{C}\right)$. Quenching the red-brown colored reaction mixture after 10 min with ethanol gave an approximately 20:1 mixture of 3-bromoisoquinoline $\mathbf{3 b}$ and 1bromoisoquinoline $\mathbf{1 b}$, from which $\mathbf{3 b}$ could be isolated in ca $70 \%$ yield by column chromatography on silica gel. The $\mathbf{3 b}: \mathbf{1 b}$ ratio did not change after ageing the solution of the lithiated species for $1 \mathrm{~h}$ at $-70^{\circ} \mathrm{C}$, or upon raising the solution temperature to $-40{ }^{\circ} \mathrm{C}$. Therefore this probably corresponds to the thermodynamic ratio of the lithiated species $\mathbf{7}$ and $\mathbf{8}$. When 3 bromisoquinoline was reacted with $n$-butyllithium under the usual conditions, and the reaction mixture was quenched with ethanol, a complex mixture not containing isoquinoline was obtained, as judged by TLC. This mixture gave a strong positive Beilstein test and rapidly reduced silver nitrate in aqueous methanol solution. Thus, it is very likely that one of the components of the mixture was the dihydroisoquinoline 9 . This result, and the formation of a small amount of the lithio species 8 on reaction of the dibromo compound 6 with $n$-butyllithium, implied that 3lithioisoquinoline derivatives should be preparable providing that the 1-position is substituted with a suitable blocking group. If this substituent were removable, then this operation would be functionally equivalent to the generation of 3-lithioisoquinoline. 
<smiles>Brc1cc2ccccc2c(Br)n1</smiles>

6

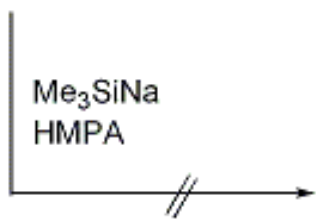<smiles>Clc1nc(Br)cc2ccccc12</smiles>

7<smiles>C=C(C)C(C)(C)C(=O)Cl</smiles><smiles>C[SiH3]c1nc(Br)cc2ccccc12</smiles>

10<smiles>CCOC(C)(C)O</smiles>

8

$3 b$<smiles>Brc1cc2ccccc2cn1</smiles>

$1 b$

\section{Scheme 2}

The trimethylsilyl moiety, which has been used as a temporary blocking group for pyridines $^{12}$, was first considered to protect position-1. The desired silylated compound 10, could not, however, be prepared from either the lithium compound $\mathbf{7}$ and chlorotrimethylsilane, or from the dibromo compound $\mathbf{6}$ with trimethylsilyl sodium in hexamethylphosporic triamide ${ }^{13}$ at room temperature, probably for steric reasons (Scheme 2).

The methylthio moiety was then selected as a position-1 blocking group, since it should be removable with Raney nickel, and after oxidation to the sulfone should be susceptible to nucleophilic displacement. The required methylthio compound $\mathbf{5 b}$ was prepared in very high yield from the dibromide 6 and sodium thiomethoxide (Scheme 3) in DMF at room temperature $(<1 \mathrm{~h})$. Trace amounts of 1,3-bis-(methylthio)isoquinoline $\mathbf{1 1}$ were also formed in this reaction. This latter substance was also slowly $(19 \mathrm{~h})$, but efficiently produced from $\mathbf{6}$ and excess sodium thiomethoxide (DMF / rt). 


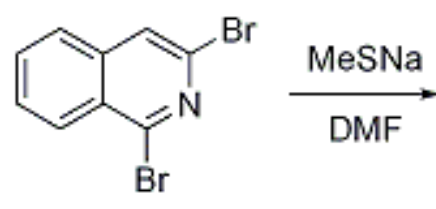

6<smiles>CSc1nc(Br)cc2ccccc12</smiles>

$5 \mathbf{b}$<smiles>CSc1cc2ccccc2c(SC)n1</smiles>

11

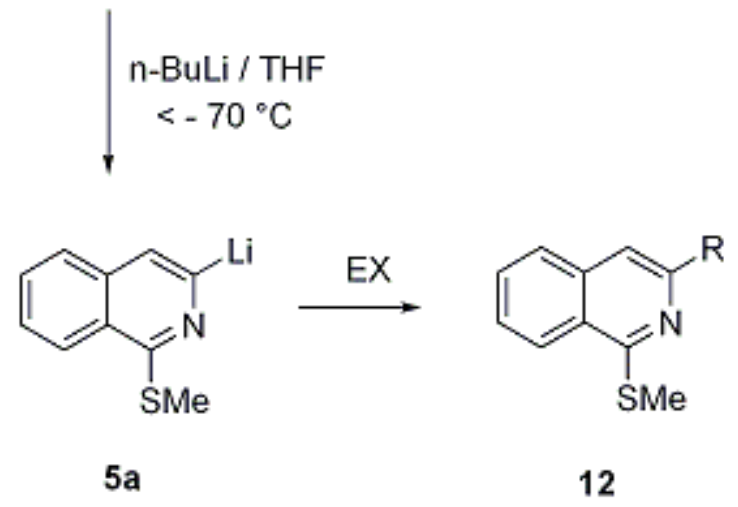

\section{Scheme 3}

1-Methylthio-3-bromoisoquinoline $5 \mathbf{b}$ reacted rapidly with an equimolar amount of $n$-butyllithium in THF $\left(\mathrm{T}<-70{ }^{\circ} \mathrm{C}\right)$ to generate a red colored solution of the lithium compound 5a. Protonolysis of this solution with ethanol gave 1-methylthioisoquinoline 12a $(\mathrm{R}=\mathrm{H})$ in $85 \%$ yield (Scheme 3 and Table 1). The lithium species 5a was also reacted with other electrophilic reagents, including alkyl iodides, DMF, DMA, and methyl chloroformate, with varying degrees of efficiency (Table 1). In those cases where the product yields were not high, considerable amounts of the protonolysis product 12a were also isolated (Table 1, entries 3 and 5). When preparing the aldehyde $12 \mathrm{~d}(\mathrm{R}=\mathrm{CHO})$, it was vital to quench the reaction mixture with two equivalents of hydrochloric acid. If water was used, the aldehyde was rapidly transformed into the primary alcohol 13 (Scheme 4), which must stem from a Cannizzaro reaction under the basic workup conditions. No attempt was made to isolate the other Cannizzaro product, i.e., the carboxylic acid 14, from the basic aqueous phase. The use of methyl chloroformate to prepare the methyl ester $12 \mathrm{f}(\mathrm{R}=\mathrm{COOMe})$ was complicated by the formation of the symmetrical ketone $\mathbf{1 5}$ as a significant byproduct. The amount of this material could be minimized by bolus addition of a large excess of methyl chloroformate to $5 \mathrm{a}$ at $-78^{\circ} \mathrm{C}$.<smiles>CSc1nc(CO)cc2ccccc12</smiles>

13<smiles>CSc1nc(C(=O)O)cc2ccccc12</smiles>

14<smiles>CSc1nc(C(=O)c2cc3ccccc3c(SC)n2)cc2ccccc12</smiles>

15<smiles>[R]c1cc2ccccc2cn1</smiles>

$16 \mathrm{a} R=\mathrm{Me}$ 16b $\mathrm{R}=\mathrm{COOMe}$

\section{Scheme 4}


Table 1. Reaction of 1-methylthio-3-lithioisoquinoline 5a with electrophilic reagents. Generation of 1-methylthio-3-substituted isoquinolines 12

\begin{tabular}{ccccc}
\hline Entry & EX & Product & R & \% Yield \\
\hline 1 & EtOH & 12a & H & 85 \\
2 & MeI & $\mathbf{1 2 b}$ & $\mathrm{Me}$ & 74 \\
3 & $n-\mathrm{BuI}$ & $\mathbf{1 2 c}$ & $n-\mathrm{Bu}^{\mathrm{b}}$ & 19 \\
4 & $\mathrm{DMF}$ & $\mathrm{CHO}$ & 89 \\
5 & $\mathrm{12d}$ & $\mathrm{COMe}^{\mathrm{c}}$ & $57-62$ \\
6 & $\mathrm{DMA}^{\mathrm{ClCO}}{ }_{2} \mathrm{Me}$ & $\mathbf{1 2 f}$ & $\mathrm{CO}_{2} \mathrm{Me}^{\mathrm{d}, \mathrm{e}}$ & 45 \\
\hline
\end{tabular}

${ }^{\mathrm{a}}$ Yield of chromatographically pure material unless indicated otherwise.

${ }^{\mathrm{b}} \mathbf{1 2 a}$ Obtained in $47 \%$ yield.

${ }^{\mathrm{c}}$ 12a Obtained in 17-25 \% yield.

${ }^{\mathrm{d}}$ Yield of crystallized product.

e 15 Obtained in $32 \%$ yield.

The methylthio moiety could be removed with Raney nickel in boiling methanol from those derivatives of $\mathbf{1 2}$ which were tolerant to such reducing conditions. Thus, $12 \mathbf{b}$ and $\mathbf{1 2 f}$ were converted into 3-methylisoquinoline $1 \mathbf{6 a}$ and methyl isoquinoline-3-carboxylate $\mathbf{1 6 b}$, respectively. This desulfurization therefore generates products which are formally derived from the hypothetical 3-lithioisoquinoline 3a. Much more important, however, is that the methodology described herein should make a wide variety of 1,3-disubstituted isoquinolines readily accessible. This could be accomplished by selective replacement of the 1-bromo group in $\mathbf{6}$, either by nucleophilic substitution, or metal catalyzed coupling processes, and subsequent lithiation at C-3. Alternatively, such compounds should be available from 12 by oxidation to the corresponding sulfones, followed by displacement of methylsulfinate by appropriate nucleophiles. $^{14,15}$ 


\section{Experimental Section}

General Procedures. Melting points were measured on a Mel-Temp II melting point apparatus and are not corrected. NMR spectra were measured in deuteriochloroform. THF was freshly distilled from sodium / benzophenone before use. Column chromatographic separations were effected using 230-400 mesh silica gel or 150 mesh neutral alumina deactivated with a suitable amount of water. The columns were packed dry, successively layered with the crude reaction mixtures (absorbed onto the stationary phase; dichloromethane), and sand, and then eluted with the appropriate solvent system(s). "Worked up in the usual way" indicates that the reaction extract was washed with saturated $\mathrm{NaCl}$ solution, dried over anhydrous sodium sulfate, and then the solvent was removed in vacuo. Homophthalimide was prepared in $85 \%$ yield (after crystallization from acetic acid) by heating a 1:1.15 mixture of homophthalic acid and urea at $180{ }^{\circ} \mathrm{C}$ for 15 min. $^{16}$ 1,3-Dibromoisoquinoline 6 was prepared from homophthalimide by the method of Sanders, et. al. ${ }^{11}$

1-Methylthio-3-bromoisoquinoline $5 \mathrm{~b}$ and 1,3-bis-(methylthio)isoquinoline (11). Solid sodium thiomethoxide $(0.640 \mathrm{~g}, 9.13 \mathrm{mmol})$ was added all at once to a stirred solution of the dibromo compound 6 (2.296 g, $8.0 \mathrm{mmol})$ in anhydrous DMF $(80 \mathrm{~mL})$ at room temperature (argon atmosphere). After $1 \mathrm{~h}$ the reaction mixture was diluted with a large volume of water and extracted with toluene. The extract was washed with water, and after the usual workup, the crude, solid product was crystallized from hexane to give material $(1.751 \mathrm{~g})$ with $\mathrm{mp} 101.5$ $102{ }^{\circ} \mathrm{C}$. The mother liquor was evaporated in vacuo and the residue was absorbed onto neutral alumina (1.5 g, deactivated with $4.5 \mathrm{wt} \%$ water) and purified by column $(3.5 \mathrm{x} 10 \mathrm{~cm})$ chromatography on the same stationaryphase $(99.5 \mathrm{~g})$ using hexane $(50 \mathrm{~mL}$ fractions $)$ as the eluant. Fractions 3-5 contained additional $6(0.256 \mathrm{~g}) \mathrm{mp} 101.5-103{ }^{\circ} \mathrm{C}$ (total yield of pure 6, $2.007 \mathrm{~g}, 98.7 \%$ ). Further elution of the column with hexane gave trace amounts of compound 11 which was best obtained as described below. Recrystallization of $\mathbf{6}$ did not change its $\mathrm{mp} ;{ }^{1} \mathrm{H}$ NMR $\delta 2.70(\mathrm{~s}, 3 \mathrm{H}), 7.54(\mathrm{~m}, 2 \mathrm{H}), 7.65(\mathrm{~m}, 2 \mathrm{H}), 8.41(\mathrm{dd}, \mathrm{J}=8.4,0.9 \mathrm{~Hz}, 1 \mathrm{H}) ;{ }^{13} \mathrm{C}$ NMR $\delta$ 13.24, 119.49, 124.62, 125.77, 126.24, 127.19, 131.03, 134.70, 137.10, 161.56. Anal. Calcd. for $\mathrm{C}_{10} \mathrm{H}_{8} \mathrm{BrNS}$ : C, 47.25; H, 3.17; N, 5.51. Found: C, 47.34; H, 3.16; N, 5.54.

1,3-Bis-(methylthio)isoquinoline (11). Sodium thiomethoxide $(0.223 \mathrm{~g}, 3.18 \mathrm{mmol})$ was added in one portion to a stirred solution of $6(0.287 \mathrm{~g}, 1.0 \mathrm{mmol})$ in dry DMF $(10 \mathrm{~mL})$ at room temperature (argon). The reaction mixture was worked up after $19 \mathrm{~h}$ in the manner described above. The crude product was absorbed onto neutral alumina $\left(1 \mathrm{~g}, 3 \mathrm{wt} \% \mathrm{H}_{2} \mathrm{O}\right)$ and purified by column $(2.2 \times 17 \mathrm{~cm})$ chromatography on neutral alumina (62 g) using ethyl acetate-hexane (2.5:97.5; $20 \mathrm{~mL}$ fractions) as the eluant. Fractions 4-6 contained crystalline $\mathbf{1 1}(0.187 \mathrm{~g})$ which on crystallization from hexane had mp $66-67.5{ }^{\circ} \mathrm{C} ;{ }^{1} \mathrm{H}$ NMR $\delta 2.66(\mathrm{~s}, 3 \mathrm{H}), 2.71(\mathrm{~s}, 3 \mathrm{H}), 7.18(\mathrm{~d}$, $\mathrm{J}=0.9 \mathrm{~Hz}, 1 \mathrm{H}), 7.42(\mathrm{~m}, 1 \mathrm{H}), 7.58(\mathrm{~m}, 2 \mathrm{H}), 8.08(\mathrm{ddd}, \mathrm{J}=0.9,1.9,8.1 \mathrm{~Hz}, 1 \mathrm{H}) ;{ }^{13} \mathrm{C}$ NMR $\delta$ 13.43, 14.50, 112.72, 124.98, 125.04, 26.17, 126.37, 131.06, 136.58, 152.17, 160.32. Anal. Calcd. for $\mathrm{C}_{11} \mathrm{H}_{11} \mathrm{NS}_{2}$ : C, 59.69; H, 5.01; N, 6.33. Found: C, 59.78; H, 4.96; N, 6.47. 


\section{Lithiation of 1-methylthio-3-bromoisoquinoline $5 b$ and reaction of the lithio compound $5 a$} with electrophilic reagents. $N$-Butyllithium in cyclohexane $(0.57 \mathrm{~mL}$ of a $1.89 \mathrm{M}$ solution, $1.08 \mathrm{mmol})$ was added all at once to a stirred solution of $5 \mathbf{b}(0.254 \mathrm{~g}, 1.0 \mathrm{mmol})$ in dry THF ( $15 \mathrm{~mL}, \mathbf{5 b}$ is not soluble in lesser volumes at low temperature) cooled to $<-75{ }^{\circ} \mathrm{C}$ in a Dry Iceacetone bath (argon atmosphere). Ten minutes thereafter, the appropriate electrophilic reagent was added, and after $1.5 \mathrm{~h}$ at $<-70{ }^{\circ} \mathrm{C}$, the reaction was quenched, the cooling bath was removed, and when the temperature had reached ambient, the reaction mixture was worked up by adding ice-water and the product was extracted with toluene. The extract was washed successively with water and saturated $\mathrm{NaCl}$ solution. After the usual treatment, the crude product was purified as described below for the specific derivative of 12 .

1-Methylthioisoquinoline (12a). Prepared by adding ethanol $(1 \mathrm{~mL})$ and $10 \mathrm{wt} \%$ aqueous $\mathrm{NH}_{4} \mathrm{Cl}(1 \mathrm{~mL})$ at $-78{ }^{\circ} \mathrm{C}$. The crude product was absorbed onto neutral alumina $(1 \mathrm{~g}, 3 \mathrm{wt} \%$ $\left.\mathrm{H}_{2} \mathrm{O}\right)$, and purified by column $(2.2 \times 13 \mathrm{~cm})$ chromatography on alumina $(51 \mathrm{~g})$ using ethyl acetate-hexane $(5: 95,10 \mathrm{~mL}$ fractions $)$ as the eluant. The oily product $(0.149 \mathrm{~g}, 85.0 \%)$ was found in fractions 3-7. ${ }^{1} \mathrm{H}$ NMR $\delta 2.71(\mathrm{~s}, 3 \mathrm{H}), 7.32(\mathrm{dd}, \mathrm{J}=5.7,0.7 \mathrm{~Hz}, 1 \mathrm{H}), 7.55(\mathrm{~m}, 1 \mathrm{~h}), 7.65$ (m, 1H), 7.74 (bd, J = 7.9 Hz, 1H), $8.19(\mathrm{dd}, \mathrm{J}=8.3,1.0 \mathrm{~Hz}, 1 \mathrm{H}), 8.32(\mathrm{~d}, \mathrm{~J}=5.7 \mathrm{~Hz}, 1 \mathrm{H}) ;{ }^{13} \mathrm{C}$ NMR $\delta 13.31,117.25,124.96,127.39,127.48,127.52,130.68,135.69,142.31,160.61$. The picrate was prepared in ethanol and after recrystallization from ethanol, the solid showed a double mp 156.5-157.5, then 161.5-162.5 ${ }^{\circ} \mathrm{C}$. Anal. Calcd. for $\mathrm{C}_{16} \mathrm{H}_{12} \mathrm{~N}_{4} \mathrm{O}_{7} \mathrm{~S}$ : C, 47.52; H, 2.99; N, 13.86. Found: C, 47.36; H, 2.84; N, 13.75 .

1-Methylthio-3-methylisoquinoline (12b). Prepared from methyl iodide $(0.08 \mathrm{~mL}, 0.182 \mathrm{~g}$, $1.28 \mathrm{mmol})$. The crude product was absorbed onto neutral alumina $\left(1.0 \mathrm{~g}, 4.5 \mathrm{wt} \% \mathrm{H}_{2} \mathrm{O}\right)$ and purified by column $(2.2 \times 13 \mathrm{~cm})$ chromatography on alumina $(50 \mathrm{~g})$, using hexane $(15 \mathrm{~mL}$ fractions) as the eluant. The product was eluted as an oil $(0.141 \mathrm{~g}, 74.5 \%)$ in fractions 5-14. On long standing it crystallized, mp 35-36 ${ }^{\circ} \mathrm{C} ;{ }^{1} \mathrm{H}$ NMR $\delta 2.62(\mathrm{~s}, 3 \mathrm{H}), 2.70(\mathrm{~s}, 3 \mathrm{H}), 7.13(\mathrm{bs}, 1 \mathrm{H})$, 7.45 (ddd, $\mathrm{J}=8.4,6.7,1.8 \mathrm{~Hz}, 1 \mathrm{H}), 7.58$ (ddd, $\mathrm{J}=8.4,6.7,1.2 \mathrm{~Hz}, 1 \mathrm{H}), 7.64$ (dd, J = 8.1, $0.8 \mathrm{~Hz}$, $1 \mathrm{H}), 8.14(\mathrm{ddd}, \mathrm{J}=8.4,1.8,0.9 \mathrm{~Hz}, 1 \mathrm{H}) ;{ }^{13} \mathrm{C}$ NMR $\delta 13.22,24.65,115.22,124.79,125.69$, $126.29,126.90,130.48,136.61,151.12,159.36$. The picrate was prepared in ethanol and after crystallization from ethanol it had mp 161.5-163.5 ${ }^{\circ} \mathrm{C}$. Anal. Calcd. for $\mathrm{C}_{17} \mathrm{H}_{14} \mathrm{~N}_{4} \mathrm{O}_{7} \mathrm{~S}$ : C. 48.80; H, 3.37; N, 13.39. Found: C, 48.64; H, 3.26; N, 13.25.

1-Methylthio-3-n-butylisoquinoline (12c). Prepared using $n$-butyliodide $(0.15 \mathrm{~mL}, 0.243 \mathrm{~g}$, $1.32 \mathrm{mmol})$. The crude product was absorbed onto neutral alumina $\left(1.0 \mathrm{~g}, 3 \mathrm{wt} \% \mathrm{H}_{2} \mathrm{O}\right)$ and purified by column $(2.2 \times 14.5 \mathrm{~cm})$ chromatography on neutral alumina $(55 \mathrm{~g})$ using hexane (20 $\mathrm{mL}$ fractions) as the eluant. The product was eluted as an oil $(0.045 \mathrm{~g}, 19.5 \%)$ in fractions 8-21. Further elution with ethyl acetate-hexane (10:90) gave the protonolysis product 12a (0.083 g, $47.4 \%$ ). 12c $\mathrm{Had}^{1} \mathrm{H}$ NMR $\delta 0.96(\mathrm{t}, \mathrm{J}=7.3 \mathrm{~Hz}, 3 \mathrm{H}), 1.41$ (sextet, $\left.\mathrm{J}=7.4 \mathrm{~Hz}, 2 \mathrm{H}\right)$, $1.81(\mathrm{~m}, 2 \mathrm{H}), 2.71(\mathrm{~s}, 3 \mathrm{H}), 2.86(\mathrm{t}, \mathrm{J}=7.6 \mathrm{~Hz}, 2 \mathrm{H}), 7.12(\mathrm{~s}, 1 \mathrm{H}), 7.46(\mathrm{ddd}, \mathrm{J}=8.3,6.8,1.5 \mathrm{~Hz}$, 1H), $7.58(\mathrm{ddd}, \mathrm{J}=8.1,6.8,1.3 \mathrm{~Hz}, 1 \mathrm{H}), 7.66(\mathrm{bd}, \mathrm{J}=8.1 \mathrm{~Hz}, 1 \mathrm{H}), 8.13(\mathrm{dd}, \mathrm{J}=8.3,0.9 \mathrm{~Hz}$, $1 \mathrm{H}) ;{ }^{13} \mathrm{C}$ NMR $\delta$ 13.22, 14.46, 22.84, 31.97, 38.04, 114.68, 124.76, 125.89, 126.27, 127.07, $130.38,136.61,155.14,159.20$. The picrate was prepared in ethanol and after crystallization 
from ethanol it had mp 107-108 ${ }^{\circ} \mathrm{C}$. Anal. Calcd. for $\mathrm{C}_{20} \mathrm{H}_{20} \mathrm{~N}_{4} \mathrm{O}_{7} \mathrm{~S}: \mathrm{C}, 52.17 ; \mathrm{H}, 4.38 ; \mathrm{N}, 12.17$. Found: C, 52.14; H, 4.32; N, 12.12 .

1-Methylthio-3-formylisoquinoline (12d). Prepared using anhydrous DMF $(0.3 \mathrm{~mL}, 0.283 \mathrm{~g}$, $3.9 \mathrm{mmol})$. The reaction mixture was quenched by adding $1.022 \mathrm{M} \mathrm{HCl}(2.0 \mathrm{~mL})$ at $-75^{\circ} \mathrm{C}$ before it was left to reach ambient temperature. The crude, solid product was taken up in the minimum amount of ethyl acetate-hexane (25:75) and applied to a dry packed column (3.5 $\mathrm{x}$ $8.5 \mathrm{~cm})$ of silica gel $(40 \mathrm{~g})$ which had been layered with a little sand and then the aldehyde 12d was eluted with the same solvent system (20 mL fractions). Compound 12d was obtained from fractions $2-5$ as a solid $(0.181 \mathrm{~g}, 89.0 \%), \mathrm{mp} 101.5-104{ }^{\circ} \mathrm{C}$. After crystallization from hexane, it had mp 104.5-106.5 ${ }^{\circ} \mathrm{C}$; IR $\left(\mathrm{CHCl}_{3}\right) 1706 \mathrm{~cm}^{-1}$; ${ }^{1} \mathrm{H}$ NMR $\delta 2.79$ (s, 3H), 7.73 (m, 2H), 7.94 (dd, $\mathrm{J}=7.0,2.3 \mathrm{~Hz}, 1 \mathrm{H}), 8.04(\mathrm{~s}, 1 \mathrm{H}), 8.24(\mathrm{bdd}, \mathrm{J}=7.9,1.5 \mathrm{~Hz}, 1 \mathrm{H}), 10.19(\mathrm{~s}, 1 \mathrm{H}) ;{ }^{13} \mathrm{C}$ NMR $\delta$ 13.34, 118.42, 125.13, 129.33, 129.79, 130.21, 131.51, 134.93, 146.29, 161.99, 193.93. Anal. Calcd. for $\mathrm{C}_{11} \mathrm{H}_{9} \mathrm{NOS}$ : C, 65.00; H, 4.46; N, 6.89. Found: C, 64.81; H, 4.38; N, 6.94.

1-Methylthio-3-hydroxymethylisoquinoline (14). If, in the synthesis of 12d, the reaction mixture was quenched with water instead of dilute $\mathrm{HCl}$, a mixture of the aldehyde 12d and the primary alcohol 14 was obtained. The mixture was absorbed onto a column $(2.2 \times 8 \mathrm{~cm})$ of silica gel $(15 \mathrm{~g})$ in the minimum volume of ethyl acetate-hexane $(25: 75)$ and elution with this solvent system (10 $\mathrm{mL}$ fractions) gave the solid aldehyde ( $0.094 \mathrm{~g}, 46.2 \%)$ in fractions $1-3$, and the solid alcohol $14(0.0485 \mathrm{~g}, 23.6 \%)$ in fractions 7-11. Crystallization of this solid from cyclohexane containing a small amount of ethyl acetate gave pure 14, mp 82-83 ${ }^{\circ} \mathrm{C}$; ${ }^{1} \mathrm{H} \mathrm{NMR} \delta$ $2.70(\mathrm{~s}, 3 \mathrm{H}), 3.40$ (bt, J = 4.0 Hz, 1H), 4.83 (d, J = 4.0 Hz, 2H), 7.26 (bs, 1H), 7.53 (ddd, J = 8.4, $6.8,1.5 \mathrm{~Hz}, 1 \mathrm{H}), 7.64(\mathrm{ddd}, \mathrm{J}=8.0,6.8,1.3 \mathrm{~Hz}, 1 \mathrm{H}), 7.72(\mathrm{bd}, \mathrm{J}=8.0 \mathrm{~Hz}, 1 \mathrm{H}), 8.17$ (dd, J = 8.4, $0.8 \mathrm{~Hz}, 1 \mathrm{H}) ;{ }^{13} \mathrm{C}$ NMR $\delta 13.39,65.08,113.15,124.96,126.74,127.16,127.51,131.04,136.24$, 151.66, 160.40. Anal. Calcd. for $\mathrm{C}_{11} \mathrm{H}_{11} \mathrm{NOS}$ : C, 64.36, H, 5.40; N, 6.82 . Found: C, 64.37; H, $5.31 ; \mathrm{N}, 6.90$.

1-Methylthio-3-acetylisoquinoline (12e). Prepared from anhydrous N,N-dimethylacetamide $(0.3 \mathrm{~mL}, 0.281 \mathrm{~g}, 3.23 \mathrm{mmol})$. The reaction mixture was quenched with $1.022 \mathrm{M} \mathrm{HCl}(2.0 \mathrm{~mL})$ at $-75^{\circ} \mathrm{C}$, before it was warmed to room temperature. The crude product was absorbed onto silica gel $(1.0 \mathrm{~g})$ and purified by column $(3.4 \times 13 \mathrm{~cm})$ chromatography on silica gel $(62 \mathrm{~g})$ using ethyl acetate-hexane $(10: 90)$ as the eluant $(20 \mathrm{~mL}$ fractions). The protonolysis product 12a $(0.030-0.044 \mathrm{~g}, 17.1-25.1 \%)$ was found in fractions 5 and 6 and the acetyl compound 12e $(0.123-0.134 \mathrm{~g}, 56.6-61.7 \%) \mathrm{mp} 101-106^{\circ} \mathrm{C}$ was present in fractions $7-13$. Crystallization of this material from cyclohexane gave pure 12e mp 110.5-111.5 ${ }^{\circ} \mathrm{C}$; IR $(\mathrm{KBr}) 1696 \mathrm{~cm}^{-1} ;{ }^{1} \mathrm{H} \mathrm{NMR}$ $\delta 2.76(\mathrm{~s}, 3 \mathrm{H}), 2.81(\mathrm{~s}, 3 \mathrm{H}), 7.69(\mathrm{~m}, 2 \mathrm{H}), 7.91(\mathrm{dd}, \mathrm{J}=7.2,1.7 \mathrm{~Hz}, 1 \mathrm{H}), 8.13(\mathrm{~d}, \mathrm{~J}=0.8 \mathrm{~Hz}, 1 \mathrm{H})$, $8.21(\mathrm{ddd}, \mathrm{J}=7.7,1.9,0.8 \mathrm{~Hz}, 1 \mathrm{H}) ;{ }^{13} \mathrm{C}$ NMR $\delta 12.95,26.42,116.41,124.39,128.32,129.01$, 129.28, 130.70, 134.79, 146.40, 159.97, 200.27.

\section{Methyl 1-methylthioisoquinoline-3-carboxylate $12 f$ and bis-(1-methylthio-3-} isoquinolyl)ketone (15). Prepared by adding methyl chloroformate $(0.3 \mathrm{~mL}, 0.367 \mathrm{~g}$, $3.88 \mathrm{mmol}$ ) as a bolus to a maximally magnetically agitated solution of the lithio compound $5 \mathbf{a}$ at $-78{ }^{\circ} \mathrm{C}\left(10^{\circ} \mathrm{C}\right.$ temperature rise $)$. The reaction was quenched by the addition of water $(2 \mathrm{~mL})$ at 
$-78{ }^{\circ} \mathrm{C}$ before it was left to reach room temperature. The crude crystalline product was heated with cyclohexane ( ca $3 \mathrm{~mL})$, and on cooling the very insoluble, pure, ketone 15 (0.060 g, $31.9 \%$ ) was obtained with mp $175-176{ }^{\circ} \mathrm{C}$; IR (KBR) $1662 \mathrm{~cm}^{-1}$; ${ }^{1} \mathrm{H}$ NMR $\delta 2.60(\mathrm{~s}, 6 \mathrm{H}), 7.73$ $(\mathrm{m}, 4 \mathrm{H}), 7.94(\mathrm{dd}, \mathrm{J}=7.5,1.8 \mathrm{~Hz}, 2 \mathrm{H}), 8.26(\mathrm{dd}, \mathrm{J}=8.2,1.0 \mathrm{~Hz}, 2 \mathrm{H}), 8.31(\mathrm{~s}, 2 \mathrm{H}) ;{ }^{13} \mathrm{C} \mathrm{NMR} \delta$ 13.28, 121.28, 125.08, 128.40, 129.31, 129.54, 131.22, 135.26, 147.79, 160.08, 192.95. Anal. Calcd. for $\mathrm{C}_{21} \mathrm{H}_{16} \mathrm{~N}_{2} \mathrm{OS}_{2}$ : C, 66.99; H, 4.28; N, 7.44. Found: $\mathrm{C}, 67.13 ; \mathrm{H}, 4.31 ; \mathrm{N}, 7.60$. The cylohexane mother liquor from above was evaporated in vacuo and the solid residue was dissolved in an ethyl acetate-hexane mixture $(20: 80 ; 10 \mathrm{~mL})$ and applied to a dry packed column $(3.4 \times 10 \mathrm{~cm})$ of silica gel $(48 \mathrm{~g})$. Elution with the same solvent system (15 mL fractions) gave the solid ester $12 \mathrm{f}(0.120 \mathrm{~g})$ admixed with a little of the ketone 15. Crystallization of this material from hexane gave $12 \mathrm{f}(0.106 \mathrm{~g}, 45.4 \%) \mathrm{mp} 92-94{ }^{\circ} \mathrm{C}$. Recrystallization from hexane gave pure 12f mp 96-97.5 ${ }^{\circ} \mathrm{C}$; IR (KBr) $1722 \mathrm{~cm}^{-1} ;{ }^{1} \mathrm{H}$ NMR $\delta 2.80(\mathrm{~s}, 3 \mathrm{H}), 4.02(\mathrm{~s}, 3 \mathrm{H}), 7.71(\mathrm{~m}, 2 \mathrm{H})$, $7.89(\mathrm{dd}, \mathrm{J}=7.5,1.9 \mathrm{~Hz}, 1 \mathrm{H}), 8.23(\mathrm{~s}, 1 \mathrm{H}), 8.24(\mathrm{dd}, \mathrm{J}=7.4,1.4 \mathrm{~Hz}, 1 \mathrm{H}) ;{ }^{13} \mathrm{C} \mathrm{NMR} \delta 13.29$, 53.01, 121.03, 125.07, 128.79, 129.67, 131.32, 135.21, 141.00, 161.42, 166.74. Anal. Calcd. for $\mathrm{C}_{12} \mathrm{H}_{11} \mathrm{NO}_{2} \mathrm{~S}$ : C, 61.78; H, 4.75; N, 6.00. Found: C, 61.67; H, 4.77; N, 6.06.

\section{Raney nickel desulfurization of $12 b$ and $12 \mathrm{f}$ to 3 -methylisoquinoline 16a and methyl}

isoquinoline-3-carboxylate (16b). Raney nickel catalyst (0.5-0.6 g) which had been suspended in methanol to remove water, was added to a solution of the methylthio compound $(0.129 \mathrm{~g}$, $0.68 \mathrm{mmol}$ of $12 \mathbf{b} ; 0.093 \mathrm{~g}, 0.4 \mathrm{mmol}$ of $\mathbf{1 2 f})$ in methanol $(10 \mathrm{~mL})$ and the mixture was stirred under reflux (argon atmosphere). For 12b, the same amount of Raney nickel was added at the end of 1.25 and $2.5 \mathrm{~h}$. The reaction was complete by $3.75 \mathrm{~h}$. For 12f, an additional portion of Raney nickel was added at the end of $1 \mathrm{~h}$ and the reaction was complete at the end of $2 \mathrm{~h}$. The mixture was filtered through Celite, the solid was washed well with methanol, and the filtrate was evaporated to dryness in vacuo. To isolate pure 16a, the residue was slurried with hexane, filtered and evaporated in vacuo to give 3-methylisoquinoline 16a $(0.083 \mathrm{~g}, 85.2 \%), \mathrm{mp} 61$ $63{ }^{\circ} \mathrm{C}$. A mixed melting point with an authentic material was undepressed and the ${ }^{1} \mathrm{H}$ NMR spectrum was superimposable on that of a commercial material. For $\mathbf{1 6 b}$, the methanol soluble residue was slurried with methyl acetate, and after workup as for 16a, crystalline $\mathbf{1 6 b}$ (27 \% yield, not optimized), identical by the usual criteria with a commercial specimen was obtained.

\section{References}

1. Gilman, H.; Soddy, T. S. J. Org. Chem. 1957, 22, 565.

2. Pohlke, R.; Strehlow, W.; Mueller-Calgan, H.; Seyfried, C. German Offen. 2, 626, 629, 1977.

3. Vaughan, L. G. J. Organometal. Chem. 1980, 190, C56.

4. Sainsbury, M.; Brown, D.W.; Dyke, S.F.; Clipperton, R.D.J.; Tonkyn, W.R. Tetrahedron. 1970, 26, 2239. 
5. Ota, T.; Terashima, M. J. Heterocycl. Chem. 1987, 24, 377.

6. Starrett, J.E.; Tortolani, D.R.; Mansuri, M.M.; Meanwell, N.A. U.S. Patent. 5, 559, 248, 1996.

7. Guzman, A. Instituto de Química. Universidad Nacional Autónoma de México, México, D.F. Personal communication.

8. Abarca, B.; Ballesteros, R.; Gómez-Aldaravi, E.; Jones, G. J. Chem. Soc. Perkin Trans I, 1985, 1897.

9. Abarca, B.; Ballesteros, R.; Mojarred, F.; Jones, G.; Mouat, D.J. J. Chem. Soc. Perkin Trans. I. $1987,1865$.

10. Abarca, B.; Mojarred, F.; Jones, G.; Phillips, C.; Ng, N.; Wastling, J. Tetrahedron. 1988, 44, 3005.

11. Sanders, G.M.; van Dijk, M.; den Hertog, H.J. Rec. Trav. Chim. Pays-Bas. 1974, 93, 198.

12. (a) Tsukazaki, M.; Snieckus, V. Heterocycles. 1993, 35, 689. (b) Schlosser, M.; Bobbio,

C.; Raussis, T. J. Org. Chem. 2005, 70, 2494.

13. Shippey, M.A.; Dervan, P.B. J. Org. Chem. 1977, 42, 2654.

14. Hayashi, E.; Tamura, Y. Yakugaku Zasshi. 1970, 90, 594; Chem. Abstr. 1970, 73, 35,192.

15. Barlin, G.B.; Brown, W.V. J. Chem. Soc. [B]. 1967, 736.

16. Crockett, G.C.; Swanson, B.J.; Anderson, D.R.; Koch, T.H. Synth. Commun. 1981, 11, 447. 